\title{
A SURVEY OF DOCTORS' ATTITUDES TO SMOKING
}

\author{
BY \\ CHARLES FLETCHER, C.B.E., M.D., F.R.C.P. \\ Department of Medicine, Royal Postgraduate Medical School, London, W.12 \\ AND \\ RICHARD DOLL, M.D., D.Sc., F.R.C.P., F.R.S. \\ M.R.C. Statistical Research Unit
}

Many doctors who used to smoke cigarettes have, since the risks became known, stopped smoking and there is now a far smaller proportion of cigarette smokers among doctors than among the general public (R.C.P., 1962; Doll and Hill, 1964). This abstention from cigarette smoking should, on the evidence of the effects of cigarette smoking, have given these doctors the expectation of a longer and healthier life, but it is possible that it has deprived them of the benefits of smoking which many smokers claim. The Committee on Smoking and Air Pollution of the Royal College of Physicians, concerned about this balance of benefit and deprivation, asked us to enquire whether doctors who had stopped smoking thought that they had suffered any consequent inconveniences which might have outweighed the advantages.

\section{MeTHods}

In 1951, a questionnaire on smoking habits was sent to all doctors whose addresses were known to the British Medical Association and who were resident in Britain. Since the B.M.A. keeps track of all doctors in Britain, whether or not they are members, these doctors comprised practically the entire medical profession of the country. Of the male doctors $67 \%$ replied to the questionnaire (Doll and Hill, 1956). Subsequently, in 1957 and 1966, further questionnaires on smoking habits were sent to the survivors of the original respondents and on each occasion replies were received from approximately 98 per cent. The present investigation was confined to male doctors aged 45-64 in 1966 who stated that they had smoked only cigarettes. They were divided into five categories according to their smoking histories, recorded in 1966, as follows:

(i) regular smokers: smoking in 1951, 1957 and 1966

(ii) irregular smokers: smoking in 1966 but exsmokers in 1957

(iii) ex-smokers in 1966: stopped < 5 years

(iv) ex-smokers in 1966: stopped 5-9 years

(v) ex-smokers in 1966: stopped 10-14 years
Samples of 100 were drawn at random from categories (i), (iii), (iv) and (v), but owing to paucity of numbers the sample from category (ii) was limited to 50 (Table I).

Questionnaires, shown on pages 151-153, were sent in the autumn of 1967 to all these doctors. The numbers who replied are also shown in Table $I$. The 150 doctors who had stated they were smoking in 1966 received questionnaire A. One was ill, one refused, and $148(99 \%)$ returned the questionnaire. Twenty had stopped smoking so returned the questionnaire incomplete. Seventy-four (58\%) of the continuing smokers, having stopped smoking at some time for at least a week, answered the questions about difficulties and consequences of stopping; of the 37 continuing smokers who had stated in 1957 that they had stopped smoking, three $(8 \%)$, curiously, now denied ever having stopped smoking for as long as a week. The $\mathbf{3 0 0}$ who reported that they had stopped smoking in 1966 received questionnaire B. Four had died, one refused, and $295(98 \%)$ replied. Seventeen had started smoking again.

\section{RESULTS}

The changes in smoking habits between 1966 and 1967 (Table II) suggest a slight continuing trend for more smoking doctors to stop $(14 \%)$ than for ex-smokers to start again $(6 \%)$ but the difference between these percentages is not significant. The proportion of irregular smokers who had stopped $(26 \%)$ was appreciably greater than the proportion of regular smokers who had stopped $(7 \%)$.

\section{ReASONS FOR STOPPING SMOKING}

Many doctors gave more than one reason for having stopped smoking (Table III). The proportion of doctors giving various reasons were similar for smokers and ex-smokers except that ex-smokers more often gave risk of future ill-health, expense, and setting an example as reasons. References to these three reasons account for all the greater number of reasons given by ex-smokers. It is notable that 
TABLE I

SAMPLE OF DOCTORS INVESTIGATED AND RESPONSE TO QUESTIONNAIRE

\begin{tabular}{|c|c|c|c|c|c|c|c|c|}
\hline \multirow{3}{*}{ Result } & \multicolumn{3}{|c|}{ Smokers $1966^{*}$} & \multicolumn{4}{|c|}{ Ex-smokers 1966} & \multirow{3}{*}{$\begin{array}{l}\text { All } \\
\text { Doctors } \\
\text { Written } \\
\text { to }\end{array}$} \\
\hline & \multirow{2}{*}{ Regular* } & \multirow{2}{*}{ Irregulart } & \multirow{2}{*}{ Total } & \multicolumn{3}{|c|}{ Years Stopped } & \multirow{2}{*}{ Total } & \\
\hline & & & & $<5$ & $5-9$ & $10-14$ & & \\
\hline $\begin{array}{l}\text { No response } \\
\text { Died } \\
\text { III } \\
\text { Refused } \\
\text { Replied }\end{array}$ & $\begin{array}{r}0 \\
1 \\
1 \\
98\end{array}$ & $\begin{array}{r}0 \\
0 \\
0 \\
50\end{array}$ & $\begin{array}{r}0 \\
1 \\
1 \\
148\end{array}$ & $\begin{array}{r}2 \\
0 \\
1 \\
97\end{array}$ & $\begin{array}{r}2 \\
0 \\
0 \\
98\end{array}$ & $\begin{array}{r}0 \\
0 \\
0 \\
100\end{array}$ & $\begin{array}{r}4 \\
0 \\
1 \\
295\end{array}$ & $\begin{array}{r}4 \\
1 \\
2 \\
443 \\
\end{array}$ \\
\hline All samples & 100 & 50 & 150 & 100 & 100 & 100 & 300 & 450 \\
\hline Numbers available & 2,932 & 165 & 3,097 & 716 & 558 & 829 & 2,103 & 5,200 \\
\hline
\end{tabular}

- Regular smokers were smoking in 1951, 1957, and 1966

tIrregular smokers had been ex-smokers in 1957 but were smoking in 1966

TABLE II

SMOKING HABITS 1966 AND 1967

\begin{tabular}{|c|c|c|c|c|c|c|c|c|}
\hline \multirow{3}{*}{$\begin{array}{l}1967 \\
\text { Habits }\end{array}$} & \multicolumn{3}{|c|}{ Smokers 1966} & \multicolumn{4}{|c|}{ Ex-smokers 1966} & \multirow{3}{*}{$\begin{array}{c}\text { All } \\
\text { Doctor } \\
\text { who } \\
\text { replied }\end{array}$} \\
\hline & \multirow{2}{*}{ Regular } & \multirow{2}{*}{ Irregular } & \multirow{2}{*}{ Total } & & rs stop & & Total & \\
\hline & & & & $<5$ & $5-9$ & $10-14$ & & \\
\hline $\begin{array}{l}\text { Unchanged } \\
\text { Changed }\end{array}$ & $91 \quad(91 \%)$ & $\begin{array}{ll}37 & (74 \%) \\
13 & (26 \%)\end{array}$ & $\begin{aligned} 128 & (86 \%) \\
20 & (14 \%)\end{aligned}$ & $\begin{array}{r}91 \\
6\end{array}$ & $\begin{array}{r}91 \\
7\end{array}$ & $\begin{array}{r}96 \\
4\end{array}$ & $\begin{array}{rr}278 & (94 \%) \\
17 & (6 \%)\end{array}$ & $\begin{array}{r}406 \\
37\end{array}$ \\
\hline Total & 98 & 50 & 148 & 97 & 98 & 100 & 295 & 443 \\
\hline
\end{tabular}

TABLE III

REASONS FOR STOPPING SMOKING (Percent of doctors giving reasons in parentheses)

\begin{tabular}{|c|c|c|c|c|c|}
\hline \multirow{2}{*}{ Reason } & \multicolumn{3}{|c|}{$\begin{array}{c}1966 \\
\text { Smokers }\end{array}$} & \multirow{2}{*}{$\begin{array}{c}\text { Ex-smokers } \\
1966\end{array}$} & \multirow{2}{*}{$\begin{array}{c}\text { All } \\
\text { Doctors } \\
\text { who } \\
\text { stopped }\end{array}$} \\
\hline & $\begin{array}{l}\text { Reg- } \\
\text { ular }\end{array}$ & $\begin{array}{l}\text { Irreg- } \\
\text { ular }\end{array}$ & Total & & \\
\hline $\begin{array}{l}\text { Cough } \\
\text { Catarrh, sore } \\
\text { throats, colds } \\
\text { Dyspnoea } \\
\text { Other symptoms } \\
\text { or illness }\end{array}$ & $\begin{array}{r}6 \\
8 \\
3 \\
14\end{array}$ & $\begin{array}{r}7 \\
6 \\
1 \\
10\end{array}$ & $\begin{array}{r}13(18 \%) \\
14(19 \%) \\
4(5 \%) \\
24(32 \%)\end{array}$ & $\begin{array}{l}60(22 \%) \\
41(15 \%) \\
13(5 \%) \\
68(24 \%)\end{array}$ & $\begin{array}{l}73(20 \%) \\
53(15 \%) \\
20(6 \%) \\
89(26 \%)\end{array}$ \\
\hline Total: symptoms & 31 & 24 & $55(74 \%)$ & $182(66 \%)$ & $235(67 \%)$ \\
\hline $\begin{array}{l}\text { Risk of future ill } \\
\text { health } \\
\text { To set example } \\
\text { To show control } \\
\text { Expense } \\
\text { Lost desire } \\
\text { Other } \\
\text { Not known }\end{array}$ & $\begin{array}{l}7 \\
6 \\
9 \\
5 \\
3 \\
3 \\
0\end{array}$ & $\begin{array}{r}13 \\
4 \\
9 \\
7 \\
0 \\
3 \\
0\end{array}$ & $\begin{array}{l}20(27 \%) \\
10(14 \%) \\
18(24 \%) \\
12(16 \%) \\
3(4 \%) \\
6(8 \%) \\
0(0 \%)\end{array}$ & $\begin{array}{r}156(56 \%) \\
82(29 \%) \\
58(21 \%) \\
77(28 \%) \\
8(3 \%) \\
23(8 \%) \\
7(3 \%)\end{array}$ & $\begin{aligned} 176 & (50 \%) \\
92 & (27 \%) \\
76 & (21 \%) \\
89 & (26 \%) \\
11 & (3 \%) \\
29 & (8 \%) \\
7 & (2 \%)\end{aligned}$ \\
\hline All doctors & 40 & 34 & 74 & 278 & 352 \\
\hline $\begin{array}{l}\text { Reasons per } \\
\text { doctor }\end{array}$ & 1.6 & 1.8 & 1.7 & 2.1 & \\
\hline
\end{tabular}

not much more than one half of the ex-smokers made any reference to risk of future ill-health as a reason for their having stopped. Of those who gave this reason the majority, $70 \%$, said, in answer to question 4, that they would have continued smoking but for this risk.

\section{Difficulty in Stopping SMoking}

It was to be expected that those who had stopped smoking would have found this easier to do than those who had continued to smoke (Table IV). Thirty-three percent of regular smokers who had ever tried to stop, $18 \%$ of those who had succeeded temporarily, and $17 \%$ of those who had managed to stop had found it 'very difficult'; conversely, $35 \%$ of regular smokers, $41 \%$ of irregular smokers, and $53 \%$ of ex-smokers had found it quite easy.

The duration of the difficulty was inevitably short, or was not stated by most of the smokers who had stopped and started again (Table V) but the difficulty had lasted less than six months in about half $(53 \%)$ of those who had experienced difficulty but had remained ex-smokers. In the other half the difficulty had lasted under one, one, or two or more years in equal proportions. In all but three-quarters of the ex-smokers, the hankering had eventually

TABLe IV DIFFICULTY IN STOPPING

\begin{tabular}{|c|c|c|c|c|c|}
\hline \multirow[b]{2}{*}{ Difficulty } & \multicolumn{3}{|c|}{ Smokers } & \multirow{2}{*}{$\begin{array}{c}\text { Ex-smokers } \\
1966\end{array}$} & \multirow{2}{*}{$\begin{array}{c}\text { All } \\
\text { Doctors } \\
\text { who } \\
\text { stopped }\end{array}$} \\
\hline & $\begin{array}{c}\text { Reg- } \\
\text { ular }\end{array}$ & $\begin{array}{c}\text { Irreg- } \\
\text { ular }\end{array}$ & Total & & \\
\hline $\begin{array}{l}\text { Very d } \\
\text { Rathe } \\
\text { Quite } \\
\text { Not st }\end{array}$ & $\begin{array}{r}13 \\
12 \\
14 \\
1\end{array}$ & $\begin{array}{r}6 \\
13 \\
14 \\
1\end{array}$ & $\begin{array}{|rr|}19 & (26 \% \\
25 & (34 \% \\
28 & (38 \%) \\
2 & (3 \%)\end{array}$ & $\begin{array}{|rr|}48 & (17 \%) \\
81 & (29 \%) \\
147 & (53 \%) \\
2 & (1 \%) \\
\end{array}$ & $\begin{array}{rr}67 & (19 \\
106 & (30 \\
175 & (50 \\
4 & (1\end{array}$ \\
\hline 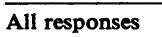 & 40 & 34 & $\overline{74(101 \%)}$ & $\overline{278(100 \%)}$ & $\overline{351}$ \\
\hline
\end{tabular}


TABLE V

DURATION OF DIFFICULTY IN S'TOPPING

\begin{tabular}{|c|c|c|c|c|}
\hline $\begin{array}{l}\text { Duration } \\
\text { (months) }\end{array}$ & $\begin{array}{c}\text { Smokers } \\
1966\end{array}$ & $\mid \begin{array}{c}\text { Ex-smokers } \\
1966\end{array}$ & & $\begin{array}{l}\text { All } \\
\text { octors } \\
\text { who } \\
\text { opped }\end{array}$ \\
\hline $\begin{array}{l}\text { Less than } 1 \\
1-5 \\
6-11 \\
12-23 \\
24-59 \\
60 \text { or more } \\
\text { Not stated }\end{array}$ & $\left.\begin{array}{rr}10 & (23 \%) \\
14 & (32 \%) \\
2 & (5 \%) \\
0 \\
1 \\
17\end{array}\right\} \begin{array}{l}(2 \%) \\
(39 \%)\end{array}$ & \begin{tabular}{rr|}
14 & $(11 \%)$ \\
54 & $(42 \%)$ \\
20 & $(16 \%)$ \\
15 & $(12 \%)$ \\
15 & $(12 \%)$ \\
3 & $(2 \%)$ \\
8 & $(6 \%)$
\end{tabular} & $\begin{array}{r}24 \\
68 \\
22 \\
15 \\
16 \\
3 \\
25\end{array}$ & $\begin{array}{c}(14 \%) \\
(39 \%) \\
(13 \%) \\
(9 \%) \\
(9 \%) \\
(2 \%) \\
(14 \%)\end{array}$ \\
\hline $\begin{array}{l}\text { All with difficulty } \\
\text { No difficulty or not stated }\end{array}$ & $44(101 \%)$ & $129(101 \%)$ & $\begin{array}{l}173 \\
178\end{array}$ & $(100 \%)$ \\
\hline All responses & 74 & 278 & 351 & \\
\hline
\end{tabular}

TABLE VI

PERSISTENCE OF DESIRE TO SMOKE

\begin{tabular}{|c|c|c|c|c|c|}
\hline \multirow{3}{*}{ Desire to smoke } & \multicolumn{5}{|c|}{ Ex-smokers 1966} \\
\hline & \multicolumn{3}{|c|}{ Years stopped } & \multirow{2}{*}{\multicolumn{2}{|c|}{ Total }} \\
\hline & $<5$ & $5-9$ & $10-14$ & & \\
\hline $\begin{array}{l}\text { Persistent } \\
\text { Occasional } \\
\text { None } \\
\text { Not stated }\end{array}$ & $\begin{array}{r}4 \\
24 \\
63 \\
0\end{array}$ & $\begin{array}{r}3 \\
18 \\
68 \\
2\end{array}$ & $\begin{array}{r}1 \\
18 \\
76 \\
1\end{array}$ & $\begin{array}{r}8 \\
60 \\
207 \\
3\end{array}$ & $\begin{array}{l}(3 \%) \\
(22 \%) \\
(74 \%) \\
(1 \%)\end{array}$ \\
\hline All responses & 91 & 91 & 96 & 278 & $(100 \%)$ \\
\hline
\end{tabular}

TABLE VII

OCCASIONS WHEN DESIRE OR NEED FELT FOR SMOKING

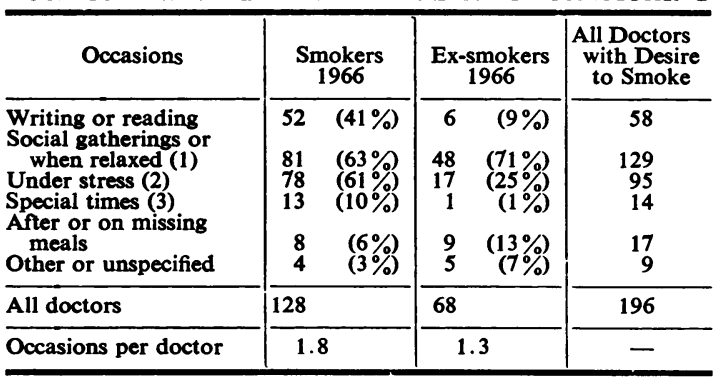

(1) Including: holidays and open air (5), cinema (1), alone (1)

(2) Including: driving (3), telephoning (1), night calls (1), committees (1)

(3) Including: "always"' (5)

been lost completely and only persisted in 3\% (Table VI). The frequency with which some desire was still felt fell as time passed from $30 \%$ in those who had stopped 1-4 years to $20 \%$ in those who had stopped 10-14 years.

Both smokers and ex-smokers gave 'social gatherings' as the occasions on which they most needed or had needed to smoke, but smokers also mentioned 'writing or reading' or 'under stress' much more often than ex-smokers (Table VII).

\section{Advantages and Disadvantages of Smoking}

Both smokers who had ever stopped and ex- smokers more often listed advantages than disadvantages from so doing (Table VIII). Fourfifths $(81 \%)$ of ex-smokers reported some advantages while less than a third $(31 \%)$ reported any disadvantages. In smokers who had ever given up the

TABLE VIII

ADVANTAGES AND DISADVANTAGES OF STOPPING

\begin{tabular}{|c|c|c|c|c|c|}
\hline \multirow{2}{*}{$\begin{array}{c}\text { Advantages } \\
\text { and } \\
\text { Disadvantages }\end{array}$} & \multicolumn{3}{|c|}{ Smokers 1966} & \multirow{2}{*}{$\begin{array}{c}\text { Ex-smokers } \\
1966\end{array}$} & \multirow{2}{*}{$\begin{array}{c}\text { All } \\
\text { Doctors } \\
\text { who } \\
\text { stopped }\end{array}$} \\
\hline & $\begin{array}{l}\text { Reg- } \\
\text { ular }\end{array}$ & $\begin{array}{l}\text { Irreg- } \\
\text { ular }\end{array}$ & Total & & \\
\hline $\begin{array}{l}\text { Advantages } \\
\text { Some } \\
\text { None } \\
\text { Not stated }\end{array}$ & $\begin{array}{r}20 \\
20 \\
0\end{array}$ & $\begin{array}{r}26 \\
7 \\
1\end{array}$ & \begin{tabular}{rr|}
46 & $(62 \%)$ \\
27 & $(36 \%)$ \\
1 & $(1 \%)$
\end{tabular} & $\begin{aligned} 224 & (81 \%) \\
47 & (17 \%) \\
7 & (3 \%)\end{aligned}$ & $\begin{array}{r}270 \\
74 \\
8\end{array}$ \\
\hline $\begin{array}{l}\text { Disadvantages } \\
\text { Some } \\
\text { None } \\
\text { Not stated }\end{array}$ & $\begin{array}{r}22 \\
18 \\
0\end{array}$ & $\begin{array}{r}22 \\
12 \\
0\end{array}$ & $\begin{array}{rr}44 & (59 \%) \\
30 & (41 \%) \\
0 & (0 \%)\end{array}$ & $\begin{array}{r}86 \\
188 \quad(31 \%) \\
4\end{array}$ & $\begin{array}{r}130 \\
218 \\
4\end{array}$ \\
\hline All replies & 40 & 34 & $74(100 \%)$ & $278(100 \%)$ & 352 \\
\hline
\end{tabular}

TABLE IX

ADVANTAGES FROM STOPPING SMOKING REPORTED BY DOCTORS WHO HAD EVER STOPPED

\begin{tabular}{|c|c|c|c|c|}
\hline Advantages & & $\begin{array}{l}\text { lokers } \\
1966\end{array}$ & Ex- & $\begin{array}{l}\text { mokers } \\
1966\end{array}$ \\
\hline $\begin{array}{l}\text { Health } \\
\text { Less upper respiratory disease } \\
\text { Less cough } \\
\text { Other }\end{array}$ & $\begin{array}{r}14 \\
11 \\
9\end{array}$ & $\begin{array}{l}(19 \%) \\
(15 \%) \\
(12 \%)\end{array}$ & $\begin{array}{l}50 \\
91 \\
85\end{array}$ & $\begin{array}{l}(18 \%) \\
(33 \%) \\
(31 \%)\end{array}$ \\
\hline $\begin{array}{l}\text { Fitness } \\
\text { Cleaner mouth } \\
\text { Improved smell/taste } \\
\text { Increased appetite/weight } \\
\text { Increased energy/alertness } \\
\text { Calmer/better sleep } \\
\text { General and others }\end{array}$ & $\begin{array}{l}3 \\
8 \\
8 \\
3 \\
2 \\
6\end{array}$ & $\begin{array}{l}(4 \%) \\
(11 \%) \\
(11 \%) \\
(3 \%) \\
(8 \%)\end{array}$ & $\begin{array}{r}7 \\
43 \\
21 \\
14 \\
8 \\
16\end{array}$ & $\begin{array}{l}(3 \%) \\
(15 \%) \\
(8 \%) \\
(5 \%) \\
(6 \%)\end{array}$ \\
\hline $\begin{array}{l}\text { Other } \\
\text { Finance } \\
\text { Less bother/mess } \\
\text { One-upmanship/example }\end{array}$ & & $\begin{array}{l}(8 \%) \\
(3 \%) \\
(1 \%)\end{array}$ & $\begin{array}{l}66 \\
42 \\
25\end{array}$ & $\begin{array}{r}(24 \%) \\
(15 \%) \\
(9 \%)\end{array}$ \\
\hline Total & 73 & & 469 & \\
\hline All doctors reporting advantages & 46 & $(62 \%)$ & 224 & $(81 \%)$ \\
\hline All doctors & 74 & $(100 \%)$ & 278 & $(100 \%)$ \\
\hline
\end{tabular}

TABLE X

DISADVANTAGES FROM STOPPING SMOKING REPORTED BY DOCTORS WHO HAD EVER STOPEPD

\begin{tabular}{|c|c|c|c|c|}
\hline \multirow{2}{*}{ 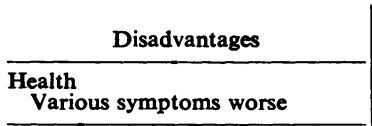 } & \multicolumn{2}{|c|}{$\begin{array}{c}\text { Smokers } \\
1966\end{array}$} & \multicolumn{2}{|c|}{$\begin{array}{c}\text { Ex-smokers } \\
1966\end{array}$} \\
\hline & 4 & $(5 \%)$ & 4 & $(1 \%)$ \\
\hline $\begin{array}{l}\text { Fitness } \\
\text { Increased appetite/weight } \\
\text { More irritable/tense/anxious } \\
\text { Other psychological }\end{array}$ & $\begin{array}{r}34 \\
23 \\
3 \\
\end{array}$ & $\begin{array}{r}(46 \%) \\
(30 \%) \\
(4 \%)\end{array}$ & $\begin{array}{r}62 \\
7 \\
1\end{array}$ & $\begin{array}{r}(22 \%) \\
(3 \%) \\
(1 \%)\end{array}$ \\
\hline $\begin{array}{l}\text { Other } \\
\text { Social embarrassment } \\
\text { Dislike of smoke/smell } \\
\text { Increased alcohol }\end{array}$ & $\begin{array}{l}2 \\
3 \\
1\end{array}$ & $\begin{array}{l}(3 \%) \\
(4 \%) \\
(1 \%)\end{array}$ & $\begin{array}{r}13 \\
13 \\
1\end{array}$ & $\begin{array}{l}(5 \%) \\
(5 \%) \\
(1 \%)\end{array}$ \\
\hline Total & 70 & & 101 & \\
\hline All doctors reporting disadvantages & 44 & $(60 \%)$ & 86 & $(31 \%)$ \\
\hline All doctors & 74 & $(100 \%)$ & 278 & $(100 \%)$ \\
\hline
\end{tabular}


advantages and disadvantages were approximately equal $(62 \%$ and $59 \%$ ). Among the indidivual advantages recorded (Table IX) loss of symptoms and improvement of health predominated. More ex-smokers than continuing smokers noted financial advantages which presumably took time to be recognized. A few men regarded appetite and weight gain as an advantage but this predominated among the disadvantages listed (Table X). Onethird of those who reverted to smoking but only $3 \%$ of those who continued to abstain became more irritable or tense.

\section{Consequences of STOPPING SMOKING}

A comparison between smokers and ex-smokers in respect of changes in their mental state is complicated by lack of comparable base lines. Table XI provides a comparison between changes in smokers over the last 10 years and changes in ex-smokers since they had stopped smoking. This comparison

TABLE XI

CHANGES IN MENTAL STATE: DURING LAST 10 YEARS FOR SMOKERS; SINCE STOPPING FOR EX-SMOKERS

\begin{tabular}{|c|c|c|c|c|c|}
\hline \multirow{2}{*}{$\begin{array}{l}\text { State } \\
\text { Tense } \\
\text { More } \\
\text { No change } \\
\text { Less } \\
\text { Not stated }\end{array}$} & \multicolumn{2}{|c|}{$\begin{array}{c}\text { Smokers } \\
1966\end{array}$} & \multicolumn{2}{|c|}{$\begin{array}{c}\text { Ex-smokers } \\
1966\end{array}$} & \multirow{2}{*}{$\begin{array}{c}\begin{array}{c}\text { All } \\
\text { Doctors }\end{array} \\
\begin{array}{c}29 \\
316 \\
47 \\
14\end{array}\end{array}$} \\
\hline & $\begin{array}{r}14 \\
90 \\
20 \\
4 \\
\end{array}$ & $\begin{array}{l}(11 \%) \\
(70 \%) \\
(16 \%) \\
\end{array}$ & $\begin{array}{r}15 \\
226 \\
27 \\
10 \\
\end{array}$ & $\begin{array}{r}(5 \%) \\
(81 \%) \\
(10 \%) \\
\end{array}$ & \\
\hline $\begin{array}{l}\text { Irritable } \\
\text { More } \\
\text { No change } \\
\text { Less } \\
\text { Not stated }\end{array}$ & $\begin{array}{r}15 \\
87 \\
22 \\
4\end{array}$ & $\begin{array}{l}(12 \%) \\
(68 \%) \\
(17 \%) \\
(3 \%)\end{array}$ & $\begin{array}{r}20 \\
226 \\
22 \\
10\end{array}$ & $\begin{array}{r}(7 \%) \\
(81 \%) \\
(8 \%) \\
(4 \%)\end{array}$ & $\begin{array}{r}35 \\
313 \\
44 \\
14\end{array}$ \\
\hline $\begin{array}{l}\text { Prone to worry } \\
\text { More } \\
\text { No change } \\
\text { Less } \\
\text { Not stated }\end{array}$ & $\begin{array}{r}12 \\
92 \\
21 \\
3\end{array}$ & $\begin{array}{l}(9 \%) \\
(72 \%) \\
(16 \%) \\
(2 \%)\end{array}$ & $\begin{array}{r}10 \\
244 \\
15 \\
9 \\
\end{array}$ & $\begin{array}{r}(4 \%) \\
(88 \%) \\
(5 \%) \\
(3 \%)\end{array}$ & $\begin{array}{r}22 \\
336 \\
36 \\
12 \\
\end{array}$ \\
\hline $\begin{array}{l}\text { Energetic } \\
\text { More } \\
\text { No change } \\
\text { Less } \\
\text { Not stated } \\
\end{array}$ & $\begin{array}{r}4 \\
70 \\
51 \\
3 \\
\end{array}$ & $\begin{array}{r}(35 \%) \\
(40 \%) \\
(2 \%) \\
\end{array}$ & $\begin{array}{r}67 \\
192 \\
10 \\
9 \\
\end{array}$ & $\begin{array}{r}(24 \%) \\
(69 \%) \\
(4 \%) \\
(3 \%) \\
\end{array}$ & $\begin{array}{r}71 \\
262 \\
61 \\
12 \\
\end{array}$ \\
\hline All states & 128 & $(100 \%)$ & 278 & $(100 \%)$ & 406 \\
\hline
\end{tabular}

is given some validity by the fact that a greater number of ex-smokers had stopped smoking 11 years previously than in any other single year and that in 1967 ex-smokers had stopped smoking, on average, for 8.6 years. Table XI shows that few doctors said they had become either more or less tense, irritable, or prone to worry, and that in each case the proportion (whether more or less) was slightly greater in smokers than in ex-smokers. The table shows that there is little difference between ex-smokers and continuing smokers in those mental states which smoking is reputed to affect, for the large majority of both smokers and ex-smokers reported no change in tenseness, irritability or worrying. Surprisingly, many more ex-smokers than smokers said they had become more energetic (24\% against $3 \%$ ) and fewer had said they had become less energetic ( $4 \%$ against $40 \%$ ).

Table XII shows a similar comparison between the weights of doctors in the two main smoking categories and the changes reported by them.

TABLE XII

MEAN WEIGHT (LB.) OF SMOKERS AND EX-SMOKERS

\begin{tabular}{|c|c|c|c|c|}
\hline \multirow[b]{2}{*}{ Date } & \multicolumn{2}{|c|}{ Smoke-s 1966} & \multicolumn{2}{|c|}{ Ex-smokers 1966} \\
\hline & Mean & \begin{tabular}{|l} 
Standard \\
Deviation
\end{tabular} & Mean & $\begin{array}{c}\text { Standard } \\
\text { Deviation }\end{array}$ \\
\hline $\begin{array}{l}\text { Ten years before reply } \\
\text { Before stopping } \\
\text { Maximum since } \\
\text { At time of reply }\end{array}$ & $\begin{array}{l}166.4 \\
174.2 \\
167.6\end{array}$ & $\begin{array}{l}22.8 \\
25.1 \\
22.2\end{array}$ & $\begin{array}{l}16 \overline{1} \\
181.5 \\
174.1\end{array}$ & $\begin{array}{l}\overline{20.7} \\
22.2 \\
20.8\end{array}$ \\
\hline
\end{tabular}

Body weights 10 years ago which were reported by doctors who had continued to smoke were similar to those reported by ex-smokers for the period before they stopped (on average 8.6 years previously) and the difference between the mean weights in the two groups was not statistically significant $(t=1.41$ $\mathrm{n}=384,0.1<\mathrm{P}<0.2$ ). Since then both groups of doctors gained and subsequently lost weight but the gain in weight was subsequently greater in those who had stopped smoking and the difference between the groups at the time of reporting was greater than it had been originally (difference between means $6.5 \mathrm{lb}$ against $3.4 \mathrm{lb}$ ) and the difference was then statistically significant $(\mathrm{t}=2 \cdot 77, \mathrm{n}=390,0.001$ $<\mathrm{P}<0.01$ ). Further evidence that the ex-smokers indeed tended to gain more weight is provided by the fact that a higher proportion of ex-smokers than of continuing smokers found it necessary to restrict their diet (Table XIII).

Only 38 of the ex-smokers (14\%) had adopted any substitute for smoking. The majority of these (32) had used sweets, two mentioned chewing gum, one snuff, and three $(1 \%)$ mentioned alcohol.

TABLE XIII RESTRICTION OF DIET

\begin{tabular}{|c|c|c|c|c|}
\hline \multirow{2}{*}{ Restriction } & \multicolumn{2}{|c|}{ A.t Time of Reply } & \multirow{2}{*}{\multicolumn{2}{|c|}{$\begin{array}{c}\begin{array}{c}\text { At any Time } \\
\text { since stopping }\end{array} \\
\begin{array}{c}\text { Ex-smokers } \\
1966\end{array}\end{array}$}} \\
\hline & $\begin{array}{c}\text { Smokers } \\
1966\end{array}$ & $\begin{array}{c}\text { Ex-smokers } \\
1966\end{array}$ & & \\
\hline $\begin{array}{l}\text { Yes } \\
\text { No } \\
\text { Not stated }\end{array}$ & $\begin{array}{rr}48 & (38 \%) \\
79 & (61 \%) \\
1 & (1 \%)\end{array}$ & $\begin{array}{rr}154 & (55 \%) \\
117 & (42 \%) \\
7 & (3 \%)\end{array}$ & $\begin{array}{r}179 \\
93 \\
6\end{array}$ & $\begin{array}{l}(64 \%) \\
(33 \%) \\
(2 \%)\end{array}$ \\
\hline All replies & $128(100 \%)$ & $278(100 \%)$ & 278 & $(99 \%)$ \\
\hline
\end{tabular}




\section{Discussion}

The high rate of response by doctors to the questionnaire that was sent to them was gratifying, not only in the validity which it confers on the findings but also in showing the continued readiness of doctors to collaborate in studies of this kind.

The fact that during the past 20 years doctors have given up smoking in greater numbers than have members of the general public may be due to the fact that 'in their daily practice they witness the tragic consequences of the habit' (Royal College of Physicians, 1962). Lynch (1963), however, showed that there was little difference in this respect between medical and non-medical graduates of the University of Edinburgh. We now find that while one half of doctors who had stopped smoking mentioned the risk of future ill-health as a reason for having stopped, two-thirds mentioned present symptoms. Of continuing smokers who had ever stopped, only one-quarter had done so on account of the remoter risks but three-quarters because of immediate symptoms. Table XIV compares the main reasons given by doctors for stopping with those given by a sample of the general public investigated by McKennell and Thomas (1967). The contrast is striking

TABLE XIV

REASONS FOR STOPPING SMOKING (\%)

\begin{tabular}{l|c|c|c|c}
\hline \multicolumn{1}{c|}{ Reason } & \multicolumn{2}{|c|}{$\begin{array}{c}\text { Adults 21 }+ \text { in } \\
\text { General Population* }\end{array}$} & \multicolumn{2}{c}{ Doctors aged 45-64 } \\
\cline { 2 - 3 } \cline { 5 - 6 } & Smokers & Ex-smoksrs & Smokers & Ex-smokers \\
\hline Expense & 27 & 42 & 16 & 28 \\
Minor ailments & 54 & 52 & 74 & 66 \\
Future health & 11 & 24 & 27 & 56 \\
Test of will power & 12 & 6 & 24 & 21 \\
No desire & 25 & 24 & 24 & 37 \\
Other & 25 & 24 & 22 & 37 \\
\hline
\end{tabular}

-From McKennell and Thomas, question 13d, p. 228

for only $11 \%$ and $24 \%$ of smokers and ex-smokers in the general public had stopped because of the remote effects on health while half mentioned minor ailments. This comparison must not be pressed too closely for the questions asked and the methods of classifying the answers were not identical in the two studies and the sample of the general public included younger people and women. The effect of age and sex, however, on the proportions giving these two groups of reasons for stopping were not great (Thomas, personal communication) so that the difference is probably real. We do not know why non-medical graduates in Edinburgh had stopped smoking but it is probable that university graduates whether medical or not pay more attention than most people to long-term risks. The fact that both doctors and laymen are more concerned with imme- diate than remote effects on their health supports the suggestion by McKennell and Thomas (1967) that this is where the emphasis should be laid in health education about the effects of smoking.

In view of the widespread belief in the strength of addiction to the cigarette, it is surprising to find that only a minority either of continuing smokers who had ever stopped or ex-smokers had found it 'very difficult' to stop while over one half of exsmokers and more than a third of smokers who had ever stopped had found it 'easy'. These figures also are similar to those reported by McKennell and Thomas in the general public. Presumably, the continuing smokers were like Mark Twain and had found a brief abstention tolerable, for only $5 \%$ of the smokers reported that the difficulty of abstention had lasted more than five months, but these figures are difficult to interpret since it is not known for how long smoking was stopped. Of those who had remained ex-smokers nearly half had had difficulty for six months or more and the difficulty lasted for a year or more in a quarter. McKennell and Thomas (1967) found much shorter duration of difficulty in the general public but they asked about 'a period of difficulty' which may have conditioned different replies.

Among some ex-smokers the desire for cigarettes persists even longer; after 10 years a quarter of the ex-smokers still had occasional hankerings after a cigarette. It may be wise to warn patients who are advised to stop smoking how long this hankering may last.

Smokers, not unexpectedly, listed more occasions on which they felt the need for cigarette smoking than did ex-smokers. The chief difference between them in the distribution of occasions of need was that more continuing smokers than ex-smokers wanted tobacco when writing or reading or when under stress. In the general public, McKennell and Thomas (1967) found that continuing smokers also mentioned stressful occasions more often than exsmokers as those on which they were likely to smoke but there was no difference between smokers and ex-smokers in their need to smoke when reading. Perhaps reading and writing are more stressful occasions for doctors struggling to keep up with the literature than for the general public reading for pleasure.

There were more heavy smokers among the regular smokers than in the other groups (Table XV). This fact together with the greater reliance of continuing smokers on cigarettes in times of stress confirms the suggestion of McKennell and Thomas that smokers vary in their degree of habituation to 
TABLE XV

PRESENT OR MOST RECENT NUMBER OF CIGARETTES SMOKED PER DAY

\begin{tabular}{|c|c|c|c|c|c|}
\hline \multirow{2}{*}{$\begin{array}{c}\text { No. of } \\
\begin{array}{c}\text { Cigarettes/ } \\
\text { day }\end{array}\end{array}$} & \multicolumn{2}{|c|}{ Smokers 1966} & \multicolumn{3}{|c|}{ Ex-smokers: Stopped 1966} \\
\hline & Regular & Irregular & $<5 \mathrm{yr}$ & $5-9 \mathrm{yr}$ & $\overline{10-14 \mathrm{yr}}$ \\
\hline $\begin{array}{l}1-9 \\
10-14 \\
15-24 \\
25-34 \\
35+\end{array}$ & $\begin{array}{l}20 \\
12 \\
39 \\
14 \\
13\end{array}$ & $\begin{array}{r}12 \\
8 \\
23 \\
6 \\
1\end{array}$ & $\begin{array}{r}19 \\
20 \\
41 \\
14 \\
3\end{array}$ & $\begin{array}{r}27 \\
25 \\
32 \\
10 \\
4\end{array}$ & $\begin{array}{r}29 \\
19 \\
41 \\
9 \\
2\end{array}$ \\
\hline Total & 98 & 50 & 97 & 98 & 100 \\
\hline Mean & 20.4 & 16.8 & 17.4 & 15.7 & 15.5 \\
\hline
\end{tabular}

cigarettes and that it is the less habituated smokers who find it easier to stop.

The primary purpose of our study was to discover how the advantages and disadvantages of smoking or not smoking were balanced between those who continued and those who had stopped smoking. In continuing smokers the advantages and disadvantages of their habit were equally balanced while the ex-smokers were far more aware of the advantages of having stopped smoking. There was little difference in the proportion of the various advantages listed by the two groups except that, with their longer discontinuance, the ex-smokers had become more aware of the financial benefits. In conformity with their expressed needs for cigarettes, the continuing smokers had found that stopping had made them more irritable or tense or anxious more often than the ex-smokers. The chief disadvantage recorded by the ex-smokers was a gain in weight. This gain was not large (on average $4.3 \mathrm{lb}$ against $1.2 \mathrm{lb}$. gained by continuing smokers over the corresponding period), but it did result in a higher proportion of ex-smokers having to restrict their diet.

In respect of the longer term psychological consequences the only significant difference between the groups was the unexpected report of the ex-smokers that they found themselves more energetic than they had been when they had been smoking, while there was no corresponding improvement in this respect among doctors who continued to smoke.

Our conclusions are that those doctors who have stopped smoking (about half of those who used to smoke cigarettes) are in general aware of more benefits than they are of any sense of deprivation, either physical or psychological, as a consequence of their abstinence.

\section{SUMMARY}

A sample of doctors who were still smoking (some of whom had previously stopped and started again) and of those who had continued to abstain were asked in 1967 to answer questions about their reasons for stopping and the consequences of so doing.

Over two-thirds of those who had ever stopped gave various respiratory symptoms as the reason for so doing: only half mentioned the risk of future ill-health. Difficulty over abstinence lasted less than six months in half and for more than two years in $20 \%$; only $3 \%$ admitted to hankering for cigarettes after five years. A need for smoking under stress was admitted to in more of the continuing than of the ex-smokers. The former were heavier smokers than the latter.

Sixty-two per cent of continuing smokers (who had ever stopped) but $81 \%$ of ex-smokers mentioned advantages from stopping smoking while $59 \%$ and $31 \%$ respectively mentioned disadvantages. There was no difference between continuing and ex-smokers during the previous 10 years in changes of tenseness, irritation or proneness to worry, but ex-smokers felt significantly more energetic. ExQ $\vec{\bullet}$ smokers had gained, on average, $4.3 \mathrm{lb}$. since्巳 stopping and had had to pay more attention to theim diet than continuing smokers.

It is concluded that doctors who have stopped smoking are in general aware of more benefits than they are of any sense of deprivation. either physical or psychological, as a consequence of their abstinence.

We are grateful to the Royal College of Physicians for covering the cost of printing the questionnaires.

\section{REFERENCES}

Doll, R., and Hill, A. B. (1956). Lung cancer and other causes of death in relation to smoking. A second report on the mortality of British doctors. Brit. med. J., 2, 1071.

(1964). Mortality in relation to smoking: ten years' observations of British doctors. Ibid., 1, 1399.

LYNCH, G. W. (1963). Smoking habits of medical and non-medical university staff. Changes since R.C.P. Report. Ibid., 1, 852.

McKennell, A. C., and Thomas, R. K. (1967). Adults' and Adolescents' Smoking Habits and Attitudes. H.M.S.O. S.S. 353/B.

Royal College OF PHysicians (1962). Smoking and Health. Pitman Medical Publishing Co. Ltd., London. 


\section{QUESTIONNAIRE 'A' FOR CONTINUING SMOKERS}

Last year you reported you were smoking

1. Are you still smoking? Yes No

(Put No if you smoke less than 1 cigarette a day or less than 4 łoz. of pipe tobacco or 2 cigars a week.)

If Yes, answer questions 2-9.

If No, please return the questionnaire without answering the remaining questions.

2. Have you ever stopped smoking for a week or more within the last 10 years? Yes No If Yes, go on to question 3 If No, skip question to 7.

3. What reasons have led you to stop smoking on these occasions? (Mark one or more reasons.)

$\begin{array}{lll}\text { cough } & \text { dyspnoea } & \text { to save expense } \\ \begin{array}{l}\text { specific illness } \\ \text { (e.g. pneumonia) }\end{array} & \begin{array}{l}\text { to reduce risk of future ill } \\ \text { health (e.g. lung cancer) }\end{array} & \text { to show self control } \\ \text { catarrh } & \text { to set an example } & \text { don't know } \\ & & \text { other reasons: specify.....: }\end{array}$

4. How difficult have you found it to stop? Very difficult Rather difficult Quite easy If stopping was difficult, how long did difficulty last ? ..................years $\quad$...................months $\quad$...........................

5. What disadvantages did you notice when you stopped smoking?

6. What advantages did you notice when you stopped smoking?

7. On what occasions do you find you most need to smoke?

When writing or reading At social gatherings When under stress

On other occasions : specify............

8. Over the past 10 years have you noticed any general change in:
(a) Feelings of tenseness?
More tense
No change
Less tense
(b) Irritability?
More irritable
No change
Less irritable
(c) Energy ?
More energetic
No change
Less energetic
(d) Proneness to worry?
More prone
No change
Less prone 
9. What was your approximate weight 10 years ago?

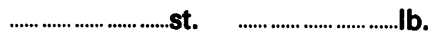

What has been your maximum weight since then?

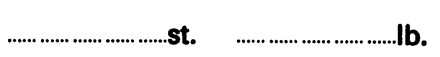

What is your present weight?

st.

Do you restrict your diet to control weight?

Yes No

\section{QUESTIONNAIRE 'B' FOR EX-SMOKERS}

Last year you reported that you had stopped smoking.

1. Are you still a non-smoker? Yes No

(A non-smoker smokes less than one cigarrette a day or less than foz. of pipe tobacco or 2 cigars a week.)

If Yes, answer questions 3-11.

If No, answer question 12.

2. When did you last stop smoking ?

3. Why did you stop smoking ? (Mark one or more reasons.)

$\begin{array}{ll}\text { cough } & \text { dyspnoea } \\ \begin{array}{l}\text { specific illness } \\ \text { (e.g. pneumonia) }\end{array} & \text { to reduce risk of future ill } \\ \text { health (e.g. lung cancer) }\end{array}$

to set an example

to save expense

don't know

other reasons: specify......

4. If smoking was not associated with an increased risk of illness would you have continued smoking ?
Yes
No
Don't know

5. How difficult was it to stop? Very difficult

Rather difficult

Quite easy

If stopping was difficult, how long did difficulty last ?

years

months days

6. Do you still hanker for tobacco? Yes

No

Occasionally

If yes or occasionally, on what occasions? (Mark one or more reasons.)

When writing or reading

At social gatherings

When under stress

On other occasions: specify............. 
7. What disadvantages have you noticed from stopping smoking ?

8. What advantages have you noticed from stopping smoking ?

9. Have you noticed any change since stopping smoking in:
(a) Feelings of tenseness?
More tense
No change
Less tense
(b) Irritability?
More irritable
No change
Less irritable
(c) Energy?
More energetic
No change
Less energetic
(d) Proneness to worry?
More prone
No change
Less prone

10. What was your approximate weight before last giving up?

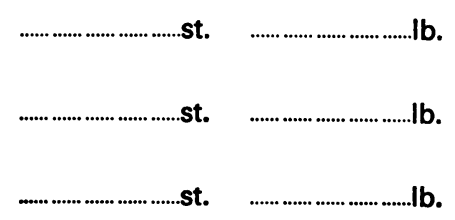

What is your present weight?

ince last giving up ?

11. Have you adopted any smoking substitute (e.g. eating sweets)?

If yes, specify

12. If you have started smoking again:

When did you start again?

How much do you now smoke?

cigarettes a day

oz. of tobacco a week in hand-rolled cigarettes

oz. of tobacco a week in a pipe

cigars a day (specify small or large)

What was your main reason for starting again?

(The layout of these questionnaires has been modified from the original for this publication). 